\title{
Literacy Development through Proper Technologies in Teaching English to Young Learners
}

\author{
Sharina Munggaraning Westhisi, Ocih Setiasih \\ Universitas Pendidikan Indonesia, Bandung, Indonesia \\ e-mail: sharina.westhisi@ student.upi.edu
}

\begin{abstract}
A literature review was conducted to describe the knowledge of Teaching English to Young Learners (TEYL) through technology aimed to develop literacy in this $21^{\text {st }}$ century. English is one of the languages in this world which should be mastered. Related to the language, language development is one of the development aspects in early childhood education curriculum 2013. In the teaching practices, there are countless media which could be used, particularly motion picture and song through technology. The technology usage in the digital era aims to assist the teachers to deliver the materials and to assist the children to comprehend the materials through amusement ways. Moreover, literacy development for young learners through phonics method may influence the language skills in English. Hence, the teachers should be able to employ the proper media through technology in teaching English to young learners which could support the children in developing the literacy. It may provoke the teaching practices in the classroom lively for instance motivating the learners in the learning process, providing fun and joyful ambiences, improving the learners' language skills, and enriching the vocabulary. The usage of proper media through technology in TEYL may improve and enhance the children's literacy in early years.
\end{abstract}

Keywords: Literacy development, technologies, English, young learners, phonics method

\section{INTRODUCTION}

The usage of technology in this era is needed by people to share the information across the world. Technology changing occured from analog to digital which influenced human resources. The phenomena took place in daily activities, for instance the social media such as Facebook, Twitter, Instagram, Snapchat, TikTok, and so forth. Besides, the smartphones and 'smart' computer devices which have countless features to speed up and to ease the business. Then, internet access could assist people to obtain and share information around the world through one touch. People should be adapted faster in this era to admit the circumstances of the technology development in order to be better in every field, particularly education.

In education, specifically Early Childhood Education (ECE), technology used as a source or media in teaching practices, for instance $e$-book, movie, song, and so forth. In teaching children, the technology could attract their attention to learn. Delivering the materials through technology becomes more interesting and could afford high motivation for children (Žumárová, 2015; Kildare \& Middlemiss, 2017; Lynch \& Redpath, 2012). Moreover, it inspires children to to build up the creativity, to connect people no matter how far, and to assist the education practitioners to exchange information and experiences of education stuff (Education Ministry, 2016). According to ECE Curriculum 2013 in Indonesia, the aspects should be considered in teaching children are spiritual and moral development, physical and motoric development, cognitve development, language development, social and emosional development, and arts development. 
Literacy consists of writing and reading skills of language development. Language is a system of symbol to explain and to establish the thought or ideas (Otto, 2015). Based on the Curriculum 2013 of ECE, the language aspects involve receptive skills (reading and listening), productive skills (speaking and writing), literacy awareness through play. Speaking of the language development in ECE, English, as a foreign language, in this era is needed due to technology and communication growth. People could access, acquire, and share the information in English to reach and connect people across the countries. Therefore, English should be taught in ECE in order to prepare children who are able to compete with others in any fields. Additionally, the children's interests and needs of English are the reasons why English should be introduced in ECE.

Foreign language acquisition, as well as English, occured if the children had acquired first language well in order to avoid confusion in language usage. Reality showed that teaching English in ECE gets various responses from society, such as parents and education practitioners. The assumptions are a five years old child is a fast learner, has great memories to learn and to have experiences, has potential to develop the learning skills as well. Thus, the exposures should support the children to develop their interests, needs, and skills. In line with Smith \& Shepard (1988) believed that education pratitioners are able to dig up their potentials in learning foreign language for their school readiness. Besides, teaching a foreign language for children could provide positive contributions since they could learn it rapidly (as cited in Santrock, 2007).

English literacy development for children is essential since it is a first step to go up in education level (Wake \& Benson, 2016). Based on the experiences, children should be able to read in English before going to international primary school. It makes sense due to the resources which used by the school are written in English. On the other hand, the survey of UNESCO showed that the reading interest of Indonesian society was low. The data showed that Indonesia was in $60^{\text {th }}$ of 61 countries for literacy (NN, 2016; Jamhari, 2016). It triggers the government to work hand in hand with education ministry in developing literacy for children. The program was designed to persuade teachers, parents, and education institutions to implement reading activity. Actually, in ECE, reading activity has been done through activities like story telling since they need a role model. This is one of ways to habituate children to love reading.

Teaching English to young learners in ECE focused on verbal skills. Yet, reading skills should be improved as well since they need to recieve countless exposures related to literacy development. It can happen when they play with friends or watch tv's programmes. Those influence children to enrich the learning experiences. Literacy development in ECE is a foundation to achieve the learning goals and objectives, thus they could continue the education level (Wake \& Benson, 2016).Reading and writing activities facilitate the children to improve and to attain the great performance at school (NHICD, 2000; Whitehurst \& Lonigan, 2001; Wang et al., 2015). Besides, it assists the children to enhance the language skills of literacy which involves phonology and letters awareness. Introduction of phonology to children in ECE could be done through introduction of letter sound as a small unit of words, letters arrangement, blending, and segmenting sounds (Mohammed \& Elghotmy., 2015). According to phonology awareness, the teachers could use the phonics method to teach early reading in ECE. The learning activities should be done in creative and amused ways to avoid boredom during learning process.

In teaching practices, teachers should provide the activities through attractive media in delivering the materials of literacy. They should know what and how to use the technology to increase children's literacy development. The researches related to the technology usage in improving literacy showed positive contributions (Belo, McKenny, Voogt, \& Bradley, 2016; Lynch \& Redpat, 2012; Wood, Grant, Gottardo, Savage, \& Evans, 2016; Chai, Ayres, \& Vail, 2016). Yet, the teachers should consider the time for using the technology in the classroom. They have to consider the proper technology which is used in learning process for children since the children love looking at pictures, motions, and songs. In line with this, Abrami, Wade, Lysenko, Marsh, and Gioko (2016) believed that the media which involved the technology by considering the children's characteristics used in teaching practices of phonology awareness for children.

In consonance with the explanation above, the author would like to examine the phonics method for developing children's literacy, to uncover the proper technology for improving children's literacy, and to unpack the values of the technology which 
accommodates children in improving language skills.

\section{METHOD}

The present study aimed to conduct a comprehensive review of educational literature about the technology usage in TEYL to develop literacy published from 2000 to 2018. There were three aspects which described related to the using of technology in TEYL for developing literacy. They were phonics method used to introduce phonology as a foundation for children in developing literacy, particulary reading skills, the usage of technology in enhancing the children's literacy of English, and the values of using the technology in strengthening the children's literacy.

\section{RESULT AND DISCUSSION}

The review of educational literature of this present study divided into three parts. First, it described one the methods in TEYL used to introduce the phonology. Second, it explained the usage of tehcnology which assisted the teachers to deliver the materials related to literacy development in TEYL. Lastly, it depicted the values of the technology usage in empowering the children's literacy.

\section{TEYL}

Phonics Method on Literacy Development in

Children would acquire the second or foreign language if they have already acquired the first language properly. In teaching practices, there are several ways to teach reading for children, one of them is phonics in order to strengthen the patterns of English (Pinter, 2006). Literacy development focused on speaking, for instance story telling, translation, and concept of phonology, which consists of the concept of alphabets, listening skills, and phonics (Ostayan, 2016). The three or five years old children have two domains, cognitive and language, which should be improved (Wortham, 2006).

Phonics mehod is a method of reading used in learning process, particularly English, which involves sounds and blending of sounds simultaneously to be a word through spoken language (Seefeldt \& Wasik, 2008). Introduction of phonology is an essential unit should be considerd in acquaring the foreign language to cover four language skills, one of them is reading skills (Genishi \& Fassler, 1999 dalam Wortham, 2006; Wahyuni \& Fauziati, n.d). Gough and Hillinger (1980) believed that there were several things in reading instructions of ECE which were prepared such as alphabets awareness, phonemic awareness, letters codes, and learning sources in spoken and written languages (as cited in Wahyuni \& Fauziati, n.d; Jamaludin et al., 2015; Huennekens \& Xu, 2015). Besides, literacy development triggers the children to know how to read and how to comprehend the texts (Lesaux, 2012; Lonigan et al., 2013).It's is notable for the teachers to assist the children comprehend the text they read since that's the point of reading. Phonics method used to introduce the sounds, then the teachers teach how to blend the sounds into a word. Logically, the children may read a story by themselves independently and the teachers lead by the hand them to comprohend what they read through some questions related to the story. Practically, the children are lost in reading due to the meaning of words. If they do not know the meaning of particular word, the teachers should define a word through pictures or any visual aids (Pinter, 2006).

Recognition of sounds could be done through spoken language. It could assist the children to comprehend the concept of sounds which used to form a word. Then, they could blend the sounds of words in reading activites. Sheriston (2016) believed that dual-route theory assist the children to improve the reading skills. Firstly, lexical route identifies a word from written to spoken language through dictionary, activates a particular word in proper spelling, and memorizes the concept of phonology. Secondly, non lexical route uses codes through sounds when spelling and uses phonem-graphem concept. The realtionship among phonem-graphem, reading skills, and writing skills influenced the alphabet concept. It is utilized in teaching reading and spelling in order to develop children's literacy.

Introduction of reading to young learners could be done by introducing the sounds in spoken language. If the students mastered the concept of sounds, they could be introduced to printed letters to assist them in developing reading skill as a part of literacy development. Furthermore, the exposures of English should be done through story telling activity since they listen to the story well in order to develop their receptive skills. By listening activity, the children could construct and comprehend the concept of learning (Pinter, 2006). For instance, the 
teacher introduces the sounds to them directly by pronouncing the letter sounds. In this activity, the children listen to the teacher and imitate how to pronounce the letter sounds properly. This is one of ways for the children to build the concept of sounds since it happens through their learning experiences which are provided by the teacher.

Additionally, the model of learning in literacy development for children is interactive model which consists of writing to reading model and vice versa (Jones \& Reutzel, 2015). Children need experiences and knowledge related to phonics in order to provide knowledge and to comprehend the meaning of vocabulary and the story structure (Whitehurst \& Loningan, 2001). Literacy development includes the activities of reading and writing. The thing that to keep in mind is the children should understand what they read. Thus, the reading activity leads them to be better and assists them to comprehend the textbooks when they go to the next level of education. The learning resources had written in English such as science, math, and social studies. Therefore, the parents and the teachers must be aware of the circumstances, needs, and interests of children in developing literacy.

The implementation of phonics method in teaching practices includes sounds, digraphs, blending sounds, segmenting word to be sounds, and consonant-vocal introduction (Greeve, 2007; Bald, 2007; Daud \& Salamah, 2016; Paul; 2003). The teachers could apply the strategies to teach them. They may use songs and rhymes to focus on patterns (Pinter, 2006). Besides, the using of visual aids, for instance card, can be exploited to help the children in comprehending the meaning of words and to enrich the vocabulary. It could collaborated with games. The activities in literacy development could be done through story telling. It is advisable to give the exposures of English to the children. Cards are employed during the story telling activity will build up their vocabulay. The teachers could explore several things from this activity as well as after doing story telling, the teachers could teach new vocabulary to the children, they could ask the questions related to the story to check their comprehension, they could ask the children to retell the story to check their comprehension and to enhance their speaking skills, they could check their spelling as well.

\section{Technology usage on Literacy Development in} TEYL

Using technology in developing literacy in ECE could be found in Curriculum 2013 of ECE. It could be done through hardware and software devices. The hardware devices include the usage of computer, tablet, handycam, and so forth. The teachers use them to deliver the materials or grab children's attention. Therefore, the teachers should know how to act and how to use the technologies wisely. It is necessary for them to integrate the knowledge of technologies (TCK), pedagogies (TPCK), and subject matter (PCK) (Koehler \& Mishra, 2009). This model could give the opportunities to pre-service teachers to comprehend and to develop the technological, pedagogical, and content knowledge related to using the technology in early literacy, especially in kindergarten (McKenney \& Voogt, 2017).

There are several useful tools used in teaching and learning literacy for children. However, the teachers should know how to use the technology tools such as computer and tablet to deliver the materials effectively. Not only that, the content and pedagogy matter considered to develop literacy. For instance, the teachers should be aware of the software used in literacy development to engage the children to be an active learner in using the language and comprehending in relation to linguistic concept which consists of pro-social, language-eliciting opportunities, as well as accommodating the children to use the creativity and use the language or linguistic in genuine ways (McKenney \& Voogt, 2009; Van Scoter, 2008).In teaching practices, the teachers use the educational technology by considering the characteristics, needs, and interests of children. The technology applied to promote and to achive the learning objectives since it is supplementary resources. Moreover, the teachers should consider the children's mental in using the technology in literacy development by developing the program together with students, teachers, and parents which discusses from health to transcultural matters, as well as emotional expression, self and co-regulation charaacteristics, the pattern of socialization, attention and memory development, motor skills, motivation and horizontal tehcnology transfer (Belletich \& Villarreal, 2017).

In this digital era, people develop countless softwares in education. Several researches examined the software usage to teach and develop literacy skills comprehensively. The finding showed that the 
use of software could encourage learning in ECE (Biancarosa \& Griffiths, 2012; Olson \& Wise, 2006; Savage et al., 2009). In selecting software used in learning activies, there are three points which involve the skills, the quality, and the level of difficulty of the software (Wood, Grant, Gottardo, Savage, \& Evans, 2016). The skills should cover four language skills such as reading, writing, speaking, and listening skills. In literacy development, the skills of sounds, letters, and words are essential to enhance the reading and writing skills. The quality means the contents and the skills that could be found in sotware. Speaking of the program, the online programs were more comprehensive learning that offline program (Wood, Grant, Gottardo, Savage, \& Evans, 2016). Then, the level of difficulties provides the steps of learning for the children. The teachers should choose the easy one to the hard one of the material in learning. The reason is to support and to construct the concept of learning in developing literacy.

The programs of softwares could be able use in literacy development, as well as Starfall, Abracadabra, and Ooka (Wood, Grant, Gottardo, Savage, \& Evans, 2016). In this programs, the aspects of literacy could be found like concept of print, alphabetic knowledge, phonological awareness, grapheme-phoneme relationship, phonics, syntactic awareness, decoding, fluency, and text comprehension. Furthermore, the teachers are able to employ the songs and rhymes from youtube to engage the children in learning process through singing and dancing. It believed that visual aids collaborated with body movements could assist the children to learn and to comprehend the words' meaning (Mamun, 2014; Marion, n.d.; Wulandari \& Apriani, 2014). In conclusion, the learning activity in developing literacy for children is various. The teachers could adapt or adopt the strategies by considering the children's characteristics, intererst, and needs in using the technology on literacy development in order to facilitate the children for achieving the learning objectives optimally.

\section{in TEYL}

Technology Values on Literacy Development

One of the values of technology usage on literacy developement is enhancing phonological awareness (Abrami, , Wade, Lysenko, Marsh, \& Gloko, 2016; Chai, Ayres, \& Vail, 2016; Neumann \& Neumann, 2015; Neumann, 2018). The findings showed that the technology usage such as computer, tablet, and software could improve the children's literacy. Then, the children could master their phonemes and enrich the vocabulary. The improvement of writing skills could be found through using of tablets which have potential to promote writing and letter knowledge (Neumann \& Neumann, 2015). According to the explanation above, the software programs inculde the aspects of the literacy as well as phonics, letters, words, and comprehension in order to reinforce the literacy skills of children and to improve the language skills (reading, writing, speaking, and listening).

The usage of songs, rhymes, movies, e-story book, and so forth affect motoric skills and socioemosional skills. For instance, the song which involves body movements engage the children to move or to dance in order to develop the motoric skill. Moreover, the iPad literacy program focused on three new alpahabet letters which the activities are matching the letters, tracing the letters, and drawing (Neumann, 2018). Those involve the children to develop cognitive and motoric skill. The socio-emotional skills can be shown when the story telling activity takes place. The children may share the experiences through stories to peers, teachers, and parents. The relationships among teachers, peers, and parents would be closer since they do the positive interactions.

One of the characteristics of children in language learning is they take great pleasure in finding and doing amusement, imagination, and movement (Pinter, 2006). Children love doing something fun through amused activities as well as playing, singing, and dancing. In this circumstances, the teachers would use the technology to provide enjoyable activities to build up the emotion and curiousity in learning process such as games and story telling since they need to use the language in the context to get the enjoyment (Bouniol, 2012). Those activities can decrease anxiety, raise positive feelings, and improve self-confidence because children do not fear of punishment or criticism while practicing the second or foreign language (Crookal, 1990 as cited in Yolageldili \& Arikan, 2011). Moreover, the atmosphere which is used in the classroom through the activities such as games and song are going to make the children acquire the language enthusiastically since they are enthusiastic and talkative learners (Halliwell, 1992 \& Moon, 2000 as cited in Gursoy, 2013). The resources in providing songs and games could be found or downloaded on youtube, google, and so forth. 


\section{CONCLUSION}

Literacy development in TEYL could be done by using the proper technology. For instance, phonics method applied as the fundamental of literacy to children since it assists the children to comprehend the concept of sounds, as the smallest unit of words. The using of the technology and phonics method could be done smoothly if the teachers and the parents pay attention to three points in using the software programs, which are the skills, the quality, and the level of difficulty. The skills consists of writing, listening, reading, and speaking. The quality focused on the content that it should cover the aspects of phonics such as sounds, letters, and words. The level difficulty aims to facilitate the children to learn the easy to hard in order to strengthen the concept and to provide clear information during learning process of literacy development.

In teaching practices, the use of technology on literacy development provides some advantages. First, it enhances the language skills which cover writing, reading, listening, and speaking skills. Second, it assists the children to understand the concept of phonology such as the concept of sounds, how to blend the sounds into a word, how to segment the words into the sounds. Third, it assists the children to comprehend the text by looking at the pictures. Then, it helps the children to enrich the vocabulary. Besides, it facilitates motoric and socioemosional skills of the children. Those aim to accomplish the development literacy optimally.

The usage of technology may provide countless values. Yet, the teachers and parents should bear in mind that it is used wisely and properly by considering children's health and proper time of using the devices.

\section{REFERENCES}

[1] Abrami, P. C., Wade, C. A., Lysenko, L., Marsh, J., \& Gioko, A. (2016). Using educational technology to develop early literacy skills in Sub-Saharan Africa, 945-964. https://doi.org/10.1007/s10639-014-9362-4.

[2] Bald, J. (2007). Using phonics to teach reading and spelling. London: Paul Chapman Publishing.

[3] Belletich, O., \&Villarreal, M. P. (2017). Knowledge of the natural and social environment in ICT consumer children. Social and Behavioral Sciences, 164-168. doi: 10.1016/j.sbspro.2017.02.058
[4] Belo, N., McKenny, S., Voogt, J., \& Bradley, B. (2016). Teacher knowledge for using technology to foster early literacy: A literature review. Computers in Human Behavior, 60, 372-383.

http://dx.doi.org/10.1016/j.chb.2016.02.053.

[5] Biancarosa, G., \& Griffiths, G. G. (2012). Technology tools to support

[6] Bouniol, P. (2012). Teaching grammar to young learners. National and Kapodistrian University of Athens Faculty of English Language and Literature ELT Methods and Practices. Retrieved on June 24, 2014 from http://eclass.uoa.gr/modules/document/file.php.

[7] Chai, Z., Ayres, K. M., \& Vail, C. O. (2016). Using an iPad app to improve phonological awareness skills in young English-language learners with disabilities. Journal of Special Education Technology, 3 (1), 14-25. DOI: $10.1177 / 0162643416633332$

[8] Daud, B., \& Salamah, U. (2016). Teaching phonics and phonemic awareness in English beginning reading. English Education Journal, 7 (3), 329-340.

[9] Education Ministyr. (2016). Seri Pendidikan Orang Tua: Mendidik Anak di Era Digital. Jakarta: Kementrian Pendidikan dan Kebudayaan.

[10] Greeve, M. S. (2007). Phoncis for dummies. New York: Wiley Publishing Inc.

[11] Gursoy, E. (2013). The development of a children's inventory for language strategies (CHILLS). Journal of Educational and Social Research, 3(7), 263-272. doi: 10.5901/jesr.2013.v3n7p263.

[12] Huennekens, M. E., \& Xu, Y. (2015). Using dialogic reading to enhance emergent literacy skills of young dual language learners. Early child development and care, 1-17. https://doi.org/10.1080/03004430.2015.1031125

[13] Jamaludin, K. A., Alias, N., \& Mohd, R. J. (2015). The effectiveness of synthetic phonics in the development of early reading skills among struggling young ESL readers. School Effectiveness and School Improvement: An International Journal of Research, Policy and Practice, 1-18. https://doi.org/10.1080/09243453.2015.1069749

[14] Jamhari. (2016). Gerakan Indonesia membaca: "Menumbuhkan budaya membaca".. Retrieved on Decemeber 15, 2016 from http://www.pauddikmas.kemdikbud.go.id/bindikmas/berita/gerak an-indonesia-membaca-menumbuhkan-budayamembaca.

[15] Jones, C. D., \& Reutzel, D. R. (2015). Write to read: Investigating the reading-writing relationship of code-level early literacy skills. Reading \& Writing Quarterly, 31 (4), 297-315. https://doi.org/10.1080/10573569.2013.850461.

[16] Kildare, C. A., \& Middlemiss, W. (2017). Impact of parents mobile dvice use on parentchild interaction: A literature review. Computers in Human Behavior, 75, 579-588. http://dx.doi.org/10.1016/j.chb.2017.06.003. 
[17] Koehler, M. J., \& Mishra, P. (2009). What is technological pedagogical content knowledge? Contemporary Issues in Technology and Teacher Education, 9(1), 60-70.

[18] Lesaux, N. K. (2012). Reading and reading instruction for children from low-income and non-English-speaking-households. The Future of Children, 22, 73-88.

[19] Lonigan, C. J., Purpura, D. J., Wilson, S. B., Walker, P. M., \& Clancy-Menchetti, J. (2013). Evaluating the components of an emergent literacy interventions for preschool children at risk for reading difficulties. Journal of Experimental Child Psychology, 114, 111-130.

[20] Lynch, J., \& Redpath, T. (2012). 'Smart' technologies in early years literacy education: A meta-narratice of paradigmatic tensions in iPad use in an Australian preparatory classroom. Journal of Early Childhood Literacy, 1-28. DOI: $10.1177 / 1468798412453150$.

[21] Mamun, MD. A. A. (2014). Effectiveness of audio-visual aids in language teaching in tertiary level. (Thesis). BRAC University, Dhaka. Retrieved on May 25, 2015 from http://dspace.bracu.ac.bd/bitstream/handle/1036 1/3288/13177014.pdf.

[22] Marion, T. (n.d). How do teacher's gestures help. young children in second language acquisition. Université Paris 7, UFR Linguistique, Laboratoire ARP. Retrieved on May 26, 2015 from http://gesture-lyon2005.enslyon.fr/article.php3?id_article=253.

[23] McKenney, S., \& Voogt, J. (2009). Designing technology for emergent literacy: The PictoPal initiative. Computers \& Education, 52(4), 719729. https://doi.org/10.1016/j.compedu.2008.11.013

[24] McKenney, S., \& Voogt, J. (2017). Expert views on TPACK for early literacy: Priorities for teacher education. Australian Journal of Education Technology, 33 (5), 1-14.

[25] Mohammed, N., Ghoneim, M., \& Elghotmy, H. E. A. (2015). The effect of a suggested multisensory phonics program on developing kindergarten pre-service teachers' EFL reading accuracy and phonemic awareness. English Language Teaching, 8(12), 124-143. https://doi.org/10.5539/elt.v8n12p124.

[26] National Institute of Child Health and Human Development (NICHD). (2000). Report of the National Reading Panel. Teaching children to read: An evidence-based assessment of the scientific research literature on reading and its implications for reading instruction (NIH Publication No. 00-4769). Washington, DC: U.S. Government Printing Office.

[27] Neumann, M. M. (2018). Using tablets and apps to enhance emergent literacy skills in young children. Early Childhood Research Quarterly,
42, $239-246$.
10.006. http://dx.doi.org/10.1016/j.ecresq.2017.10.006.

[28] Neumann, M. M., \& Neumann, D. L. (2015).
The use of touch-screen tablets at home and preThe use of touch-screen tablets at home and pre-
school to foster emergent literacy. Journal of Early Childhood Literacy, 1-18. DOI: 10.1177/1468798415619773.
[29] NN. (2016). Survei UNESCO: Minat baca masyarakat Indonesia 0,001 persen. Retrieved on December 15, 2016 from http://gobekasi.pojoksatu.id/2016/05/19/surveiunesco-minat-baca-masyarakat-indonesia-0001persen/.

[30] Olson, R., \& Wise, B. (2006). Computer-based remediation for reading and related phonological disabilities. In M. C. McKenna, L. D. Labbo, R. D. Kieffer, \& D. Reinking (Eds.), International handbook of literacy and technology (Vol. 2, pp. 57-74). Mahwah, NJ: Lawrence Erlbaum Associates Publishers.

[31] Ostayan, J. R. (2016). Early literacy skills and English language learners: An analysis of students in a title I school, Reading Psychology, 37 (8), 1-22 https://doi.org/10.1080/02702711.2016.1159634

[32] Otto, B. (2015). Perkembangan bahasa pada anak usia dini (3rd ed.). Jakarta: Prenamedia Group.

[33] Paul, D. (2003). Teaching English to children in Asia. Quarray Bay, Hongkong: Longman Asia ELT.

[34] Pinter, A. (2006). Teaching young language learners. Oxford: Oxford University Press.

[35] reading in the digital age. The Future of Children, 22(2),

[36] Santrock, J. W. (2007). Child Development. Texas: McGraw-Hill.

[37] Savage, R. S., Abrami, P., Hipps, G., \& Deault, L. (2009). A randomized controlled trial study of the Abracadabra reading intervention program in Grade 1. Journal of Educational Psychology, 101(3), 590-604.

[38] Seefeldt, C., \& Wasik, B. A. (2008). Pendidikan anak usia dini: Menyiapkan anak usia tiga, empat, dan lima tahun masuk sekolah. Jakarta: PT. Indeks.

[39] Sheriston, L. (2016). Routes to reading and spelling: Testing route theory, Reading Research Quarterly, 1-15. https://doi.org/10.1002/rrq.143.

[40] Van Scoter, J. (2008). The Potential of IT to Foster Literacy Development in Kindergarten. In J. V. Knezek (Ed.), International Handbook of Information Technology in Education (pp. 149-161). London: Springer.

[41] Wahyuni, N.T., \& Fauziati, E. (n.d.). The effectiveness of using phonics-based instructions in English reading classes to improve students' participation. The First International Conference on Child-Friendly Education, 353-368.

[42] Wake, D. G., \& Benson, T. R. (2016). Preschool literacy and the common core: A professional development model. Journal of Education and Learning, 5(3), 236-251. ISSN 1927-5250.

[43] Wang, Y., Yinb, L., McBride, C. (2015). Querterly unique predicators of early reading and writing: A one-year longitudinal study of Chinese kindergarteners. Early Childhood research Quarterly, 32, 51-59. 
[44] Whitehurst, G., \& Lonigan, C. (2001). Emergent literacy: Development from prereaders to readers. In S. B. Neuman \& D. K. Dickinson (Eds.), Handbook of early literacy research (pp. 11-29). New York: Guilford.

[45] Whitehurst, G., \& Lonigan, C. (2001). Emergent literacy: Development from prereaders to readers. In S. B. Neuman \& D. K. Dickinson (Eds.), Handbook of early literacy research (pp. 11-29). New York: Guilford.

[46] Wood, E., Grant, A. K., Gottardo, A., Savage, R., \& Evans, M. A. (2016). Software to promote young children's growth in literacy: A comparison of online and offline formats. Early Childhood Education, 1-11. DOI 10.1007/s10643-016-0779-9.

[47] Wood, E., Grant, A. K., Gottardo, A., Savage, R., \& Evans, M.. A. (2016). Software to promote young children's growth in literacy: A comparison of online and offline formats. Early
Childhood Education, 1-11. DOI 10.1007/s10643-016-0779-9.

[48] Wortham, S. C. (2006). Early childhood curriculum: Developmental bases for learning and teaching (4th ed.). New Jersey: Pearson.

[49] Wulandari, T. R., \& Apriani, D. W. (2014). Singing and dancing in English for young learners classroom. (Article). Universitas Bina Darma, Indonesia. doi: 10.7763/IPEDR. Retrieved on November 13, 2014 from http://www.ipedr.com/vol77/010ICLMC2014_N00021.pdf.

[50] Yolageldili, G., \& Arikan, A. (2011). Effectiveness of using games in teaching grammar to young learners, Elementary Education Online, 10(1). Retrieved on June 26, 2014 from http://ilkogretim-online.org.tr

[51] Žumárová, M. (2015). Computers and children's leisure time. Social and Behavioral Sciences, 176, 779-786. doi: $10.1016 /$ j.sbspro.2015.01.540 